\title{
Research on Metaphor and its Functions in Economic Text
}

\author{
X. L. Liu \\ School of Foreign Languages, China University of Geosciences, Wuhan, Hubei, P.R. China
}

\begin{abstract}
This study aims to explore metaphor models and analyze their important functions in economic text. The corpora are from the articles of The Economist and China Economic Times from 2011-2012. Metaphorical expressions are selected and classified. It is found that metaphors are pervasive in economic texts. Three functions of metaphor, namely rhetoric, cognitive and textual functions, are discussed. This research is significant in helping readers to build or strengthen metaphorical thinking for reading and writing, so as to better promote economic exchanges between China and western countries.
\end{abstract}

KEYWORD: Metaphor; Function; Economic text

\section{INTRODUCTION}

Economy is closely related to people's lives, concerning big issues like housing, inflation, finance, price, energy, employment, etc. However, some economic concepts and events are difficult to understand for ordinary people. If they are written in a very dull and abstract way, economic magazines and papers may not have great popularity. Therefore, in order to make more people understand them, a great number of metaphors are used in these articles to describe economic concepts and activities. It not only attracts people's attention but renders them a new perspective to perceive economic events. Based on Conceptual Metaphor Theory of Lakoff \& Johnson, this paper intends to talk about the main conceptual metaphors in economic texts, and explores their important functions in them.

\section{CONCEPTUAL METAPHOR THEORY}

Metaphor is a common phenomenon and people use it at any moment. British rhetorician I.A. Richards (1965) said that there may be one metaphor every three sentences in our daily conversation. Nowadays, it is commonly acknowledged that metaphor is not only a linguistic but a cognitive phenomenon. Metaphorical thinking is an important way for people to understand things and to build conceptual system. In their co-work Metaphors we live by, Lakoff \& Johnson (1980) consider that metaphor is pervasive, not only in language but in our thinking and actions. The conceptual system we think and act by is basically metaphorical in nature. They think the essence of metaphor is to use one thing to understand and experience another thing. Such metaphorical concepts as TIME IS MONEY and ARGUMENT IS WAR are deeply rooted in English culture. It can help us to understand the unknown by the known or to re-understand the known from a new perspective. Metaphor involves the interaction between two semantic domains. Each domain has its own schematic structure. Through mapping from source domain to target domain, we can better understand the latter. Lakoff \& Johnson (1999) pointed out that as a way of thinking to know the world, metaphor is based on human body experiences. That is to say, people know the world in virtue of life and social experiences by interacting with the surrounding environment.

\section{METAPHOR MODELS IN ECONOMIC TEXT}

\subsection{Corpora}

The corpora is from the articles of The Economist and China Economic Times from 2011-2012. The Economist is an English economic magazine which has a world-wide influence on reviewing economic events. China Economic Times is a Chinese economic daily and has a great popularity in China. The number of collected English and Chinese texts is 112 and 100, over 170,000 words respectively. Among them, there are 507 and 348 metaphorical expressions in both texts respectively, concerning finance, energy, stock market, housing, etc. 


\subsection{Main metaphor models}

According to the result, a great number of metaphors exist in economic text. They are in variety. From further analysis, it is found that all of these metaphors are rooted in people's life and social experiences. Some metaphors have already become conventional ones, like MONEY IS LIQUID, ECONOMY IS BUBBLE, and MARKET IS CONTAINER, which are commonly accepted by people. Four main metaphor models are discussed as follows.

\subsubsection{ECONOMY IS A PERSON}

The number of this kind of metaphor is the largest. Economy is endowed with human features: it has emotion of happiness, anger, depression and joy like human beings; it has healthy problems; it falls in love, gets married and divorces as well; it is in good mood or bad. All in all, all human features are mapped onto it. The reason why so many human metaphors appear in economic text is that people began to know the world through their own body experiences from ancient times. Shu D.F. (2000) said that a typical feature of human thinking is characterized by embodiment. That is to say, people tend to use their familiar knowledge or experiences to understand or explain an unfamiliar field. Here are some examples.

(1). Bigger fears of Greek contagion surround Serbia, Romania and Bulgaria.

(2). Alibaba and Yahoo! agree to divorce.

(3). The first-tier cities such as Beijing and Shanghai have serious indigestion.

\subsubsection{ECONOMY IS WAR}

Though most of us didn't take part in the war or on the battlefield, this doesn't prevent us from understanding the concept of "war". Through television, film, media and literary works, the schema of war has already rooted in people's minds. It involves both sides, the purpose of the war, the use of tactics and strategy, weapons, losing or winning, etc. When economy is compared to a war, the conceptual structure of war is mapped onto economy. Some descriptions like price war, promotion war, online shopping war can be seen everywhere. War metaphor can vividly describe complex and cruel reality of business competition, which make people better understand business practices. Here are some examples.

(1). Credit card offers promotion war between banks again.

(2). The EU is already is close to a trade war with China.

(3). America's economy battles uncertainty, both home-made and imported.

\subsubsection{ECONOMY IS A JOURNEY}

Almost all of the people have experiences of being on a journey. A journey has start, route and destination. The operation and development of economy is like on a journey. That the conceptual structure of a journey is systematically mapped onto the development of economy makes economic activities more concrete and vivid. The start of an economic activity is that of a journey; the goal is the destination of a journey; the economic development is the dynamic process of a journey; obstacles in economic development are the difficulties on the journey. Here are some examples:

(1). The journey to join in EU for Ukraine is very far.

2. It has been no easy road getting here, and the path ahead looks rocky.

(3). The reform of tap water has made a detour.

\subsubsection{ECONOMY IS AN ANIMAL / A PLANT}

In nature, besides human being themselves, people have better understanding about their surrounding animals and plants as well. They know the unique characteristics and habits of those animals and plants, which has become part of their life experiences. For instance, some animals have the habit of hibernation in winter; some flowers have short blossoming period. In economic text, some plants and animals are often used to describe the characteristics of economic entity. For example, larger enterprises are often called big and fierce animals, like large crocodile of real estate enterprise. Some animal metaphors have become conventional ones, like bear market or bull market. Here are some examples.

(1). Russia bulls see its entry into the WTO leading to an investment boom.

(2). Unlike the tigers, China relies very little on foreign borrowing.

(3). Some start-ups do turn out to be gazelles.

\section{FUNCTIONS OF METAPHOR}

\subsection{Four functions of metaphor mentioned by Shu D.F.}

In his book Study in Metaphor, Shu D.F. points out that generally speaking, different metaphors have different functions. For instance, some metaphor can stir images; some have cognitive function and some can create a certain atmosphere. And some metaphors have special social functions, which can reflect or strengthen the close relationship between communicators. He classified function of metaphor into four kinds: rhetoric, linguistic, cognitive and social functions. 


\subsection{Three functions of metaphor in economic text}

Metaphors in economic text do not have all of the functions mentioned above. Three functions of metaphor in economic text are discussed as follows, including rhetoric, cognitive and textural function that was talked about in one of my previous papers.

\subsubsection{Rhetoric function}

The earliest study in metaphor was done by rhetoricians. Therefore, rhetoric function of metaphor is the earliest discovered one. Like other rhetoric, the use of metaphor is to enhance the effect of language expression. Metaphor has the characteristics of economy, novelty and indirectness, which uses the limited words to express very important information to arouse readers' attention and evoke people's imagination. In economic text, titles are often written in a metaphorical way. On one hand, it can increase the appeal to readers; on the other hand, it avoids mediocrity and dullness. Only in this way, can readers have curiosity and interest in reading them. For example,

(1). The hangover

America is recovering from the debt bust faster than European countries. Why?

Jan 21 st 2012 | from the print edition

(2). The Greek crisis

The end of the marathon?

Feb 21st 2012, 5:47 by The Economist BRUSSELS

\subsubsection{Cognitive function}

Metaphor is a basic cognitive way for human beings and many basic concepts of human conceptual system are metaphorical. Some radical metaphors like TIME IS MONEY or LIFE IS A JOURNEY greatly influence and manipulate people's daily lives. Since metaphorical concepts are systematic, they have lots of entailments. Shu D.F. (2000) said that generally speaking, metaphor plays two important roles in cognition: one is to create new meaning; another is to provide a new perspective to look at things. Economy is seen as human being, war, journey, animal or plant. The features of these vehicles are mapped onto economy, which not only gives economy a new meaning but provides readers a new dimension to look at it. The examples mentioned above in 3.2 can be used as a reference.

\subsubsection{Textual function}

Miao, X.W. (2007) said that the systematicity of metaphorical concepts and the interaction between the conceptual domains of metaphor endow metaphor with textual functions. The textual function of metaphor lies in that it can be used as a strategy to construct economic texts. Metaphor can be a cohesive device through repetition and using lexical cohesion to form a semantic network to realize the deepest cohesion. Meanwhile, metaphor has the function of constructing the theme of a paragraph and that of a text to build a semantically coherent text. For the limitation of space, here is an example of thematic metaphor as the title.

\section{Alibaba and Yahoo! agree to divorce}

Yahoo! offered American cash and technology, plus a Taiwanese-born boss, Jerry Yang, who had already inspired other Chinese internet entrepreneurs. Alibaba offered access to what was then the world's biggest untapped market for ecommerce. Alas, the two firms were soon throwing plates at each other. They bickered over everything from censorship to the spin-off of Alibaba's onlinepayments business, Alipay. After more than a year of haggling, they announced a deal on May 20th that will see them separate more or less amicably.

The text is built into an organism by the title which is not only attractive but also dominates the whole text. The body is developed based on the theme of divorce. Some derivative metaphors, like throwing plates at each other, bickering, haggling, announcing a deal, and separating amicably, unites the text into a coherent one in a metaphorical way.

\section{CONCLUSION}

It is proved that a great number of metaphors exist in economic text. As a way of thinking, it has already become a basic way for people to know the economic activities based on their life and social experiences. The use of metaphor in economic text not only increases its appeal to readers but also provides them a new perspective to look at the economic world. Meanwhile, it can achieve the aim of text coherence by using limited words to maximize the effect of language. This study is significant in helping readers or learners to enhance their metaphorical thinking or awareness, so as to better understand economic articles to promote cultural and economic exchanges between China and western countries.

\section{ACKNOWLEGEMENT}

This research was financially supported by Special Fund of Central University Basic Scientific Research Expenses, Scientific Research Project and Social Science Research Project of Department of Education of Hubei Province.

\section{REFERENCES}

[1] Lakoff, G. \& Johnson, M. 1980. Metaphors We Live By. 
Chicago: University of Chicago Press.

[2] Lakoff, G.. \& Johnson, M. 1999. Philosophy in the Flesh: The Embodied Mind and Its Challenge to Western Thought. New York: Basic Books.

[3] Miao, X.W \& Liao M.Z. 2007. Research on textural function of metaphor. Foreign Language Research. (6): 5156.
[4] Richards, A. 1965. The Philosophy of Rhetoric. New York: Oxford University Press.

[5] Shu D.F. 2000. Studies in Metaphor. Shanghai: Foreign Language Education Press. 